\title{
THE OCCURRENCE OF THREE FLAGELLAR PHASES IN ARIZONA SEROTYPES
}

\author{
MARY A. FIFE, P. R. EDWARDS, \\ Communicable Disease Center, Public Health Service, \\ U.S. Department of Health, Education aud Welfare, Atlanta, Georgia \\ RIICHI SAKAZAKI, MASAAKI NOZAWA \\ Department of Bacteriology, National Institute of Health, Tokyo \\ AND MASAYOSHI MURATA \\ Department of Bacteriology, National Institute of Animal Health, Tokyo.
}

(Received: December 2nd, 1960)

Since Andrewes (1922) described "specific" and "nonspecific" flagellar antigens in several Salmonella types, the diphasic state has been recognized in hundreds of Salmonella serotypes and has been recognized also in the Arizona group (Edwards and West, 1945). Similar variations have been found in the Escherichia freundii (Citobacter) group by Edwards (1946), in the Hafnia group by Deacon (1952), and in the Aerobacter cloacae (Cloaca) group by Sakazaki and Namioka (1960).

Salmonella types which had complex phases and which gave rise to simpler types through loss variation were reported. Edwards and Bruner (1942) described S. salinatis $\left(4,12: \mathrm{d}, \mathrm{e}, \mathrm{h}: \mathrm{d}, \mathrm{e}, \mathrm{n}, \mathrm{z}_{15}\right)$ which could be changed irreversibly to $S$. san diego (4, $12:$ e, h: e, $\mathrm{n}, \mathrm{z}_{15}$ ) while Edwards, Kauffmann and Huey (1957) found that S. montgomery (11: d, a: d, e, $\mathrm{n}, \mathrm{z}_{15}$ ) was changed to $S$. luciana $\left(11: \mathrm{a}: \mathrm{e}, \mathrm{n}, \mathrm{z}_{15}\right.$ ). Both of the changes resulted from the permanent loss of the common major antigenic constituent of phases 1 and 2 through cultivation in semisolid medium which contained $\mathrm{d}$ serum. Further, Edwards (1950) observed spontaneous irreversible segregation of $\mathrm{e}, \mathrm{h}$ phases from more complex d, e, h phases. "Artificial" or induced phases often have been obtained by cultivation of salmonellae in homologous flagellar antisera. Thus, Kauffmann (1936) obtained $\mathrm{j}$ phases by cultivation of $S$. typhi in d serum and Edwards and Bruner (1939) and Bruner and Edwards (1941) obtained induced phases from $S$. abortus equi and $S$. paratyphi $A$. Such induced phases were reverted to naturally occurring antigens only with difficulty if, indeed, reversion was accomplished.

It is known that Salmonella types with similar $\mathrm{H}$ antigens yield similar induced phases. For example, salmonellae which contain antigen $d$ tend to produce $j$ phases when cultivated in homologous $\mathrm{H}$ antisera, and organisms which contained $\mathrm{b}$ antigens tend to yield $z_{33}$ phases (Edwards and Moran, 1946; Lederberg and Edwards, 1953). These induced antigens function as phase 1 if the organism which yielded them originally was diphasic.

坂崎利一・野沢正昭（国立予防衛生研究所細菌部）

村田昌芳（農林省家畜衛生試験場） 
For instance, $S$. paratyphi $B$ when cultivated in b and 1, 2 antisera yields a diphasic form having the $\mathrm{H}$ formula $z_{33}: 1,2$. Further, such induced phases replace phase 1 of other types in transduction experiments (Lederberg and Edwards, unpublished data). Thus, while various phases have been induced in enteric bacteria, these apparently were artifacts which occurred rarely, if at all, in nature and resulted from changes produced in the natural antigens. These changes were not additive changes but were substitutions and in no instance was the number of flagellar phases of the organisms increased. Diphasic organisms, after change of one of the phases to an induced antigen, still exhibited variation only between two points of reference, as did the original culture.

It was not until recently that Enterobacteriaceae which possessed three naturally occurring $\mathrm{H}$ antigens were found. Edwards and Fife (1960) recognized an Arizona serotype which had the antigenic formula 5, 29:33:21:40. The three $\mathrm{H}$ phases, 33, 21, and 40 , were known to occur naturally in other serotypes and were completely reversible at will in all directions. Later, Taylor and Lee (1960) recognized a culture of $S$. worthington which had the antigenic formula $1,13,23: \mathrm{z}: 1, \mathrm{w}: \mathrm{z}_{43}$. The third phase was known to occur naturally in a number of cultures of $S$. senftenberg. The $z_{43}$ phase could be changed to $\mathrm{z}$ or $1, \mathrm{w}$ at will and natural phase variation occurred between the $\mathrm{z}$ and $1, \mathrm{w}$ components but neither of these was induced to revert to $z_{43}$ which was irretrievably lost. LeMinor and Edwards (1960) working with S. hamilton (3, $\left.15: \mathrm{z}_{27}\right)$ found that upon cultivation in semisolid medium which contained $z_{27}$ serum a 3,15 : e, $\mathrm{h}: 1,2$ form indistinguishable from $S$. goerlitz was obtained. Here again, the e, $\mathrm{h}$ and 1,2 phases were easily reversible but it was only with difficulty in many trials that $z_{27}$ was recovered upon three occasions from the 1,2 phase. From the foregoing summary it is apparent that organisms which have three natural phases have been found only rarely and that only the triphasic Arizona type recognized by Edwards and Fife contained three natural, readily reversible flagellar antigens. The purpose of the present paper is to describe two additional Arizona serotypes which possessed three reversible phases.

\section{MATERIALS AND MeTHODS}

The two cultures to be described were isolated from the feces of normal snakes by the methods using DHL agar plate according to Sakazaki, Namioka, Osada and Yamada after enrichment with selenite broth. The methods used in the biochemical and serological examination of the culture were those described by Edwards and Ewing (1955), Edwards, Fife and Ramsey (1959), and Sakazaki, Namioka and Ishii (1959).

\section{RESULTS}

The biochemical properties of the two cultures were those of typical members of the Arizona group as detailed by Edwards, Fife and Ramsey (1959) except that culture 213459 produced indol. Both cultures produced acid and gas from lactose within 24 hours. The serological characteristics of the cultures were as follows:

Culture 2127-59 (CDC 736-60) was agglutinated strongly by Arizona O group 5 serum in slide tests and in tube tests reacted to the titer of the serum. From absorption tests it was evident that the $\mathrm{O}$ antigens of 2127-59 were not identical with those of the test strain of $\mathrm{O}$ group 5 since the titer of the serum was reduced only $50 \%$ after absorption. However, since the organism possessed no antigenic relationships to other Arizona $\mathrm{O}$ groups, the culture was classified simply as a member of $\mathrm{O}$ group 5 rather than to introduce further complexities into the Arizona scheme by the establishment of additional $\mathrm{O}$ 
subgroups.

When first tested with $\mathrm{H}$ sera, the culture reacted only with Arizona H39 serum. When a single colony of that phase was placed in semisolid medium which contained H39 serum, the organisms recovered from the spreading growth were agglutinated both by $\mathrm{H} 23$ and by $\mathrm{H} 30$ sera. These sera are known to give cross reactions so the antigen was tested with the two sera which had been mutually absorbed. Again agglutination occurred in both. The form in question then was grown in one tube of semisolid medium which contained $\mathrm{H} 39$ and absorbed $\mathrm{H} 23$ sera and in a second tube which contained H39 and absorbed H30 sera. Spreading occurred in both tubes. From the first was isolated a form which behaved as a typical H30 phase and from the second a culture which seemed identical with H23. Closer examination of these two lines revealed that this was the case and that two distinct $\mathrm{H}$ antigens were involved. The results of agglutination and absorption tests with these antigens are given in Table 1 . The data included in the table demonstrate the presence in the culture of three distinct $\mathrm{H}$ phases, one identical with the test strain of $\mathrm{H} 23$, the second identical with the test strain of H30, and the third identical with the test strain of H39.

Table 1. $\mathrm{H}$ antigens of $2127-59$

\begin{tabular}{|c|c|c|c|c|c|c|}
\hline \multirow[b]{2}{*}{ Sera } & \multicolumn{6}{|c|}{ Antigens } \\
\hline & $\begin{array}{l}\text { Arizona H23 } \\
\quad(1109-55, \\
\text { phase 1) }\end{array}$ & $\begin{array}{c}2127-59 \\
\text { (phase 1) }\end{array}$ & $\begin{array}{l}\text { Arizona H39 } \\
\text { (1158-58, } \\
\text { phase 2) }\end{array}$ & $\begin{array}{l}2727-59 \\
\text { (phase 2) }\end{array}$ & $\begin{array}{l}\text { Arizona } \mathrm{H} 30 \\
\text { (456-53, } \\
\text { phase 2) }\end{array}$ & $\begin{array}{l}2127-59 \\
\text { (phase 3) }\end{array}$ \\
\hline \multicolumn{7}{|l|}{$\begin{array}{l}\text { Arizona H23 } \\
\quad(1109-55, \text { phase } 1)\end{array}$} \\
\hline $\begin{array}{l}\text { Unabsorbed } \\
\text { Absorbed by }\end{array}$ & 12,800 & 25,600 & $<106$ & $<100$ & 6,400 & 6,400 \\
\hline $\begin{array}{l}2127-59, \text { phase } 1 \\
\text { Arizona } H 39\end{array}$ & $<100$ & $<100$ & $<100$ & $<100$ & $<100$ & $<100$ \\
\hline (1158-58, phase 2) & & & & & & \\
\hline $\begin{array}{l}\text { Unabsorbed } \\
\text { Absorbed by }\end{array}$ & $<100$ & $<100$ & 25,600 & 25,600 & $<100$ & $<100$ \\
\hline $\begin{array}{l}2127-59, \text { phase } 2 \\
\text { Arizona H30 }\end{array}$ & $<100$ & $<100$ & $<100$ & $<100$ & $<100$ & $<100$ \\
\hline $\begin{array}{l}\text { Unabsobsorbed } \\
\text { Unabsorbed by }\end{array}$ & 3,260 & 3,200 & $<100$ & $<100$ & 25,600 & 25,600 \\
\hline $2127-59$, phase 3 & $<100$ & $<100$ & $<100$ & $<100$ & $<100$ & $<100$ \\
\hline
\end{tabular}

After the presence of the three phases was proved, their reversibility was investigated. They were found to be fully reversible and any one of the three phases could be obtained from either of the other two by cultivation in the appropriate combinations of sera which had been absorbed to remove common agglutinins. Single colony isolation was interposed between each change of phase. Both antigens H23 and H39 occur in combination with phase 2 antigens in other types. Hence, both have been designated previously as phase 1 antigens. On the contrary, H30 occurs typically with phase 1 antigens and has been designated in many types as phase 2 . Therefore, the antigenic formula of $2127-59$ has been designated as $5: 23: 39: 30$. Arizona O5 is closely related to Salmonella $\mathrm{O}$ antigen 48, Arizona $\mathrm{H} 23$ to Salmonella $\mathrm{H}$ antigen $1, \mathrm{z}_{13}$, and Arizona H30 to Salmonella H antigen 1,5. Arizona H39 is identical with a new Salmonella H 
antigen $z_{47}$ which is to be described by the writers in a subsequent paper.

Culture 2134-59 (CDC 738-60) was agglutinated to the titer of Arizona O28 serum and in absorption tests removed all agglutinins from the serum.

When the $\mathrm{H}$ antigens of the culture were first examined agglutination occurred only in H33 serum. Growth of the organism in semisolid medium which contained H33 serum resulted in the recovery of a form which was agglutinated in $\mathrm{H} 25, \mathrm{H} 38$ and $\mathrm{H} 40$ sera. H38 and H40 cross react in high dilution and H33 is less closely related to H40. $\mathrm{H} 25$ is related to none of the three. Carefully absorbed aliquots H33, H38, and H40 sera were prepared so that all cross reacting were removed and the culture again was examined. The form which migrated in the presence of H33 serum again was agglutinated by $\mathrm{H} 25$ serum and by absorbed $\mathrm{H} 38$ and $\mathrm{H} 40$ sera. This form when placed in semisolid medium which contained H25 serum and absorbed H33 serum yielded a phase which was agglutinated only by the absorbed H38 and H40 sera. When placed in semisolid medium which contained absorbed H33 and H40 sera the above mentioned form yielded a phase which was agglutinated only in H25 serum. Thus, there appeared to be at least three distinct flagellar components in the culture. Efforts then were made to separate the form which agglutinated both in absorbed H38 and H40 sera into two phases which would agglutinate only with one or the other of the sera. These efforts were not successful and it appeared that a complex flagellar component was present in the culture and that this component was related to $\mathrm{H}$ antigens 38 and 40 but was identical with neither. This assumption was confirmed by agglutination and absorption tests which are detailed in Table 2.

Table 2. $\mathrm{H}$ antigens of $2134-59$

\begin{tabular}{|c|c|c|c|c|c|c|c|}
\hline \multirow[b]{2}{*}{ Sera } & \multicolumn{7}{|c|}{ Antigens } \\
\hline & $\begin{array}{c}\text { Arizona H33 } \\
\text { (466-52, } \\
\text { phase 1) }\end{array}$ & $\begin{array}{l}2134-59 \\
\text { (phase } 1)\end{array}$ & $\begin{array}{l}\text { Arizona H25 } \\
\text { (Pc 155, } \\
\text { phase 2) }\end{array}$ & $\begin{array}{l}2134-59 \\
\text { (phase 2) }\end{array}$ & $\begin{array}{l}\text { Arizona H38 } \\
\text { (1995-57, } \\
\text { phase 2) }\end{array}$ & $\begin{array}{c}\text { Arizona H40 } \\
(2907-59 \\
\text { phase } 2)\end{array}$ & $\begin{array}{l}2134-59 \\
\text { (phase } 3 \text { ) }\end{array}$ \\
\hline $\begin{array}{l}\text { Arizona } \mathrm{H} 33 \\
\quad(466-52, \text { phase } 1)\end{array}$ & & ' & & & & & \\
\hline Unabsorbed & 25,600 & 25,600 & $<100$ & $<100$ & $<100$ & $<100$ & $<100$ \\
\hline $\begin{array}{l}\text { Absorbed by } \\
2134-59, \text { phase } 1\end{array}$ & $<\mathrm{I00}$ & $<100$ & $<100$ & $<100$ & $<100$ & $<100$ & $<100$ \\
\hline \multicolumn{8}{|l|}{$\begin{array}{l}\text { Arizona H25 } \\
\quad(\text { Pc } 155, \text { phase } 2)\end{array}$} \\
\hline Unabsorbed & $<100$ & $<100$ & 6,400 & 6,400 & $<100$ & $<100$ & $<100$ \\
\hline \multicolumn{8}{|l|}{ Absorbed by } \\
\hline \multicolumn{8}{|l|}{$\begin{array}{l}\text { Arizona H38 } \\
\quad(1995-57, \text { phase } 2)\end{array}$} \\
\hline \multicolumn{7}{|l|}{ Absorbed by } & 32,00 \\
\hline $\begin{array}{l}\text { Arizona H40 } \\
(2907-59, \text { phase 2) }\end{array}$ & $<100$ & $<100$ & $<100$ & $<100$ & 6,400 & $<100$ & 400 \\
\hline 2134-59, phase 3 & $<100$ & $<100$ & $<100$ & $<100$ & 1,600 & $<100$ & $<100$ \\
\hline \multicolumn{8}{|l|}{$\begin{array}{l}\text { Arizona H40 } \\
\quad(2907-59, \text { phase } 2)\end{array}$} \\
\hline Unabsorbed & 400 & 400 & $<100$ & $<100$ & 1,600 & 25,600 & 12,800 \\
\hline \multicolumn{8}{|l|}{ Absorbed by } \\
\hline $\begin{array}{l}\text { Arizona H38 } \\
\text { (1995-57, phase 2) }\end{array}$ & $<100$ & $<100$ & $<100$ & $<100$ & $<100$ & 3,200 & 1,600 \\
\hline $2134-59$, phase 3 & $<100$ & $<100$ & $<100$ & $<100$ & $<100$ & 1,600 & $<100$ \\
\hline
\end{tabular}


It was evident that one phase of the culture was identical with Arizona H33, the second with $\mathrm{H} 25$ and the third a complex phase related to $\mathrm{H} 38$ and $\mathrm{H} 40$ but identical with neither. The reversibility of these phases was next investigated and again it was found that each of the three phases could be changed to either of the others and that these changes apparently could be continued indefinitely. Here again, single colony isolation was interposed between each change in phase. The designation of the third phase involved an arbitrary decision since it was identical neither with $\mathrm{H} 38$ nor with H40. Since the component was agglutinated to half the titre of $\mathrm{H} 40$ serum but to a much lesser degree by $\mathrm{H} 38$ serum, the phase was designated simply as $\mathrm{H} 40$. Arizona $\mathrm{H}$ antigen 33 occurred previously in combination with phase 2 antigens and was designated as phase 1. $\mathrm{H}$ antigens 25 and 40 have occurred as phase 2 in other cultures. Culture 2134-59 arbitrarily was asigned the formula $28: 33: 25: 40$. Arizona $\mathrm{O}$ antigen 28 is identical with Salmonella $\mathrm{O}$ antigen 47 of $S$. kaolack and $\mathrm{H}$ antigen 33 is closely related to Salmonella $\mathrm{H}$ antigen $\mathrm{i}$.

\section{SUMMARY}

Two Arizona cultures from snakes, each of which possessed three distinct flagellar antigens, are described. The first is represented by the antigenic formula $5: 23: 30: 39$ and the second by the formula $28: 33: 25: 40$. The phase designated as H40 in the second formula is not identical with that of the test strain but is related to both antigens $\mathrm{H} 38$ and $\mathrm{H} 40$.

\section{REFERENCES}

ANDREwES, F. W. (1922): Studies in group agglutination. I. The Salmonella group and its antigenic structure. J. Path. \& Bact., 25, 505-521.

BRUNER, D. W. \& EDWARDS, P. R. (1941): The demonstration of nonspecific components in Salmonella paratyphi $A$ by induced variation. J. Bact., 42, 467-478.

DEACON, W. E. (1952): Antigenic study of certain slow lactose fermenting Aerobacter cloacae cultures. Proc. Soc. Exper. Biol. \&Med., 81, 165-170.

EdWARDS, P. R. \& BRUneR, D. W. (1939): The demonstration of phase variation in Salmonella abortus equi. J. Bact., 38, 63-72.

EDWARDS, P. R. \& BRUNER, D. W. (1942): A description of an unusual Salmonella type with special reference to the evolution of Salmonella species. J. Bact., 44, 289-300.

EDWARDS, P. R. \& WEST, M. G. (1945): Phase variation of Andrewes in a coiliform bacterium. J. Infect. Dis., 77, 185-186.

EDWARDS, P. R. (1946): The segregation of antigens in a bacterial culture by an undescribed form of variation. J. Bact., 51, 523-530.

EDWARDS, P. R. \& MORAN, A. B. (1946): The natural occurrence of an "induced" antigen in Salmonella cultures. Proc. Soc. Exper. Biol. \& Med., 61, 241-243.

EDWARDS, P. R. (1950): Unusual antigenic variation in an enteric bacterium. Proc. Soc. Exper. Biol. \& Med., 74, 471-474.

Edwards, P. R. \& EwING, W. H. (1955): Identification of Enterobacteriaceae. Burgess, Minneapolis.

Edward, P. R., Kauffmann, F. \& Huey, C. R. (1957): A new Salmonella serotype (Salmonella montgomery). Acta Path. et Microbiol. Scandinav., 41, 517-520.

Edwards, P. R., Fife, M. A. \& RAmSey, C. R. (1959): Studies on the Arizona group of Enterobacteriaceae. Bact. Rev., 23, 155-174.

EDWARDS, P. R. \& FIFE, M. A. (1960): The occurrence of three readily reversible flagellar 
phases in an organism of the Arizona group. J. Bact., in press.

Kauffamnn, F. (1936): Ueber die diphasische Natur der Typhusbacillien. Ztschr. f. Hyg. u. Infektkr., 119, 103-118.

LEDERBERG, J. \& EDWARDS, P. R. (1953): Serotypic recombination in Salmonella. J. Immunol., $71,232-240$.

LEMINOR, L. \& EDWARDS, P. R. (1960): Precence de trois phases de 1'antigene flagellaire chez des bacteries du groupe Salmonella. Ann. Inst. Pasteur Lille, 99, 469-474.

SAKAZAKI, R., NAMIOKA, S. \& IshiI, F. (1959): Rapid biochemical and amino-acid decarboxylation tests with preserving solution for the recognition of enteric bacteria. The Bull. of the Nippon Veterinary and Zootechnical College, No. 8, 23-28.

SAKAZAKI, R., NAMIOKA, S., OsadA, A. \& YAMADA, C. (1960): A problem on the pathogenic role of Citrobacter of enteric bacteria. Jap. J. Exper. Med., 30, 13-21.

SAKAZAKI, R. \&. NAMIOKA, S. (1960): Serological studies on the Cloaca (Aerobacter) group of enteric bacteria. Jap. J. Med. Sci. \& Biol., 13, 1-12.

TAYlOR, J. \& Lee, M. M. (1960): Quoted by Taylor, J., Lee, M. M., Edwards, P. R. \& Ramsey, C. H. (1960): A new type of flagellar variation associated with new antigens in the Salmonella group. J. Gen. Microbiol., in press. 